\title{
Az arc-, állcsont-szájsebészeti aktív fekvőbetegosztályok teljesítménymutatói
}

\author{
Marada Gyula dr. ${ }^{1,2}$ - Nagy Ákos dr. ${ }^{2}$ - Sebestyén Andor dr. ${ }^{1,3}$ \\ Zemplényi Antal dr. ${ }^{4}$ - Radnai Márta dr. ${ }^{2}$ - Boncz Imre dr. ${ }^{1}$
}

\author{
${ }^{1}$ Pécsi Tudományegyetem, Egészségtudományi Kar, Egészségbiztosítási Intézet, Pécs \\ ${ }^{2}$ Pécsi Tudományegyetem, Klinikai Központ, \\ Fogorvostudományi Egyetem, Fogászati és Szájsebészeti Klinika, Pécs \\ ${ }^{3}$ Pécsi Tudományegyetem, Klinikai Központ, Pécs \\ ${ }^{4}$ Pécsi Tudományegyetem, Kancellária, Egészségügyi Gazdálkodási Igazgatóság, Pécs
}

\begin{abstract}
Bevezetés: Hazánkban az arc-, állcsont-szájsebészeti osztályok száma és szerkezete az elmúlt évtizedekben jelentős átalakuláson mentek keresztül. Célkitüzés: Vizsgálatunk célja a maxillofacialis aktív fekvőbetegosztályok aktuális teljesítménymutatóinak a bemutatása, valamint e mutatók alapján az ellátóhelyek összehasonlítása. Adatok és módszer: Elemzésünkhöz az Országos Egészségbiztosítási Pénztár által leszerződött, illetve finanszírozott ágyak számát vettük alapul. Az összevetéshez használt teljesítményadatok az Országos Egészségbiztosítási Pénztár adatbázisából származnak. A vizsgálatban a következő indikátorokat értékeltük: az ágyszámok megoszlása intézeti típus szerint, a finanszírozási esetek száma, a súlyszám összege, a case-mix index, az elszámolt ápolási napok száma, az ágykihasználtság, valamint az átlagos ápolási idő. Eredmények: A vizsgált időszakban az aktív ágyak 40\%-a (65) volt egyetemi klinikán. Ehhez hasonló megoszlást mutat a finanszírozási esetek száma is. Az egyetemi klinikákon magasabb a súlyszámöszszeg, és a case-mix index értéke is. A arc-, állcsont-szájsebészeti osztályok ágykihasználtsága (45,75\%) elmarad az országos átlagtól. Következtetés: A vizsgált időszakban az indikátorok az egyes intézményeknél jelentős eltéréseket mutattak. Orv. Hetil., 2017, 158(12), 447-453.
\end{abstract}

Kulcsszavak: súlyszámösszeg, case-mix index, ágykihasználtság, átlagos ápolási idő

\section{Performance indicators of maxillofacial surgery inpatient departments}

Introduction: In Hungary, the number and structure of the maxillofacial surgery departments underwent significant changes in recent decades. Aim: The aim of our study was to present the actual performance indicators of maxillofacial inpatient departments and based on the available data to compare the departments. Method: The study was based on the number of beds founded by the National Health Insurance Fund. Performance data were supplied by the National Health Insurance Fund Administration. The assessment included the following indicators: number of beds institutional breakdown by type, number of reimbursed cases, the weighted case number, hospital stay, bed occupancy rates and average length of stay. Results: In the examined period $40 \%$ of active beds (65) were in university hospitals. The distribution of reimbursed cases was similar. The university hospitals showed higher weighted case number and case-mix index. The oral surgery departments' bed occupancy rate $(45.75 \%)$ was below the national average. Conclusion: The indicators show significant differences among different departments in the examined period.

Keywords: cost-weight, case-mix index, bed occupancy, average length of stay

Marada, Gy., Nagy, Á., Sebestyén, A., Zemplényi, A., Radnai, M., Boncz, I. [Performance indicators of maxillofacial surgery inpatient departments]. Orv. Hetil., 2017, 158(12), 447-453.

(Beérkezett: 2016. december 9.; elfogadva: 2017. február 1.) 


\section{Rövidítések}

case-mix index = eset-összetételi index; HBCs = Homogén Betegségcsoport; OEP = Országos Egészségbiztosítási Pénztár; TVK = teljesítményvolumen-korlát

A arc-, állcsont-szájsebészet a mútétes szakmák egyik legrégebbi és legnagyobb hagyományokra visszatekintő ága. Árkövy József irányítása mellett 1908-ban alakult meg hazánkban az Egyetemi Stomatologiai Klinika, amely Európában elsőként fekvőbetegosztállyal is rendelkezett [1]. A fogászat fejlődésével szinte párhuzamosan fejlődött a maxillofacialis sebészet is, bizonyítva a két szakterület szoros kapcsolatát. A maxillofacialis sebészet fontosságát mutatja, hogy a II. világháborút követôen szinte minden nagyobb megyei kórházban volt szájsebészeti osztály. A szájsebészet kifejezés két területet ölel fel: a maxillofacialis és a dentoalveolaris sebészetet. Annak ellenére, hogy ez a két szakterület napjainkban jól elkülönült, a hazai és nemzetközi társaságok mind hangsúlyozzák a szoros összetartozásukat.

Korábban az Országos Egészségbiztosítási Pénztár (OEP) az aktív fekvőbeteg-szakellátási formák között két szakmakóddal (13-as: Fogászati ellátás és A4-es: Dentoalveolaris sebészet) is szerepeltetett fekvőbetegosztályokat. Az egészségügyi szakmai jegyzékről szóló 2/2004. (XI. 17.) EüM rendelet 2. számú mellékletének 2012. június 1-jén hatályba lépett módosítása a 0303-as szakmakódú „arc- és állcsont-szájsebészet” megnevezést 1700-as szakmakódú „arc-, állcsont-szájsebészet” megnevezésú osztályokká módosította [2]. Az utóbbi évtizedekben a maxillofacialis osztályok száma csökkent [3], és ezzel párhuzamosan a szerkezeti átstrukturálások ellenére is az ágyszámokban hasonló csökkenés figyelhető meg.

Vizsgálatunk célja az arc-, állcsont-szájsebészeti aktív fekvőbetegosztályok 2015-ös évre vonatkozó teljesítménymutatóinak bemutatása, valamint ezen mutatók alapján az ellátóhelyek összehasonlítása.

\section{Adatok és módszer}

Elemzésünkhöz az Országos Egészségbiztosítási Pénztár (OEP) által szerződött, illetve finanszírozott ágyak számát vettük alapul, amelyeket a hivatkozott 2006. évi CXXXII. törvény, illetve ennek végrehajtási utasításai

1. táblázat | Aktív fekvôbeteg- és kúraszerű ellátás összesített teljesítményadatai intézeti típus szerinti bontásban (2015)

\begin{tabular}{|c|c|c|c|c|c|c|c|c|}
\hline \multicolumn{2}{|c|}{ Intézettípus } & \multicolumn{3}{|c|}{ Szakma } & \multirow{2}{*}{$\begin{array}{l}\text { Finanszírozási } \\
\text { eset }\end{array}$} & \multirow[t]{2}{*}{ Súlyszámösszeg } & \multirow{2}{*}{$\begin{array}{l}\text { Case-mix } \\
\text { index }\end{array}$} & \multirow{2}{*}{$\begin{array}{l}\text { Elszámolt } \\
\text { ápolási nap }\end{array}$} \\
\hline Kód & Megnevezés & Kód & Megnevezés & Ágyszám & & & & \\
\hline 2 & Egyetemek & 1700 & Arc-, állcsont-szájsebészet & 65 & 4661 & 4998,75 & 1,097 & 11065 \\
\hline 4 & Megyei intézetek & 1700 & Arc-, állcsont-szájsebészet & 79 & 5416 & 4311,20 & 0,831 & 12126 \\
\hline 5 & Fővárosi intézetek & 1700 & Arc-, állcsont-szájsebészet & 8 & 510 & 357,21 & 0,718 & 1395 \\
\hline 7 & $\begin{array}{l}\text { MÁV, MH, BM, } \\
\text { egyéb intézetek }\end{array}$ & 1700 & Arc-, állcsont-szájsebészet & 10 & 589 & 617,25 & 1,066 & 2341 \\
\hline
\end{tabular}

2. táblázat |Aktív fekvőbeteg- és kúraszerú ellátás összesített teljesítményadatai intézeti bontásban (2015)

\begin{tabular}{lrrrrr}
\hline Intézet megnevezése & $\begin{array}{l}\text { Finanszírozási } \\
\text { esetszám }\end{array}$ & $\begin{array}{l}\text { Ágy- } \\
\text { szám }\end{array}$ & $\begin{array}{l}\text { Súlyszám- } \\
\text { összeg }\end{array}$ & $\begin{array}{l}\text { Súly- } \\
\text { szám/ágy }\end{array}$ & $\begin{array}{l}\text { Case-mix } \\
\text { index }\end{array}$ \\
\hline Bács-Kiskun Megyei Oktatókórház, Kecskemét & 2696 & 15 & 2249,27 & 149,95 & 0,881 \\
Békés Megyei Pándy Kálmán Kórház, Gyula & 302 & 12 & 240,85 & 20,07 & 0,897 \\
Csolnoky Ferenc Kórház, Veszprém & 273 & 10 & 286,00 & 28,6 & 1,100 \\
Debreceni Egyetem, Klinikai Központ, Debrecen & 1145 & 18 & 1279,43 & 71,07 & 1,152 \\
Jász-Nagykun-Szolnok Megyei Hetényi Géza Kórház és Rendelóintézet, Szolnok & 1061 & 7 & 651,75 & 93,10 & 0,616 \\
Markusovszky Egyetemi Oktatókórház, Szombathely & 210 & 7 & 249,86 & 35,69 & 1,217 \\
Magyar Honvédség Egészségügyi Központ, Budapest & 589 & 10 & 617,62 & 61,762 & 1,066 \\
Pécsi Tudományegyetem, Klinikai Központ, Pécs & 554 & 10 & 639,42 & 63,942 & 1,201 \\
Petz Aladár Megyei Oktató Kórház, Győr & 431 & 14 & 211,63 & 15,11 & 0,499 \\
Semmelweis Egyetem, Budapest & 975 & 26 & 1417,90 & 54,53 & 1,504 \\
Somogy Megyei Kaposi Mór Oktató Kórház, Kaposvár & 411 & 7 & 399,58 & 57,08 & 1,024 \\
Szt. János Kórház és Észak-budai Egyesített Kórház, Budapest & 510 & 8 & 357,27 & 44,65 & 0,718 \\
SZTE Szent-Györgyi Albert Klinikai Központ, Szeged & 1988 & 11 & 1665,06 & 151,36 & 0,844 \\
Zala Megyei Kórház, Zalaegerszeg & 32 & 7 & 23,84 & 3,40 & 0,850 \\
\hline
\end{tabular}


hirdettek ki. A arc-, állcsont-szájsebészeti ágyak alatt az OEP kódolási rendszere szerinti 1700-as szakmakóddal jelzett aktív kórházi ágyakat értettük. Az összevetéshez használt teljesítményadatokat az OEP adatbázisából kaptuk.

Első lépésben megvizsgáltuk az arc-, állcsont-szájsebészeti osztállyal rendelkező ellátóhelyek ágyszámmegoszlását intézeti típus szerint. Ugyancsak intézeti típus szerinti bontásban az összesített teljesítményadatok közül a finanszírozott esetek számát, a finanszírozási esetek számát, a súlyszámösszeget, a case-mix indexet, valamint az elszámolt ápolási napok számát hasonlítottuk össze (1. táblázat).

Ezt követően az aktív fekvőbetegosztályok teljesítménymutatóit vizsgáltuk az arc-, állcsont-szájsebészeti fekvőbetegosztállyal rendelkező kórházaknál, illetve klinikáknál (2. táblázat).

A teljesítménymutatók közül külön értékeltük a következőket: a case-mix index (elszámolt súlyszám és az elszámolt finanszírozási esetszám hányadosa) (1. ábra), az egyes osztályok ágykihasználtsága (a teljesített és a teljesíthetó ápolási napok hányadosa) (2. ábra), az átlagos ápolási idő (elszámolt nap és finanszírozott eset hányadosa) (3. ábra), a napi ágykihasználtság (a teljesített betegnapok és az ágyak számának adott időszakra számított átlaga) (4. ábra), valamint a napi ágykihasználtság megoszlása (5. ábra).

A magyar egészségügyi rendszer strukturális és finanszírozási kérdései máshol részletesen tárgyalásra kerültek [4-7].

\section{Eredmények}

Az 1. táblázatot vizsgálva megállapítható, hogy az arc-, állcsont-szájsebészeti osztályok teljes ágyszáma a vizsgált időszakban 162 volt. Ennek 40\%-a (65 ágy) múködik a négy egyetemi klinikán. A fennmaradó 60\%-on (97 ágy) pedig a többi tíz ellátóhely osztozik. Ezek is döntő többséggel megyei intézetek, kórházak, és a fennmaradó két intézmény pedig a fóvárosi ágyszámot gyarapítja. Az ágyszámok megoszlásával közel megegyező az elszámolt esetek száma is. A 11176 eset 42\%-át (4661 eset) látták el egyetemi klinikán. A megyei intézetek a fennmaradó esetek 48\%-át (5416 eset), a fóvárosi és egyéb intézetek pedig 10\%-át látták el a teljes esetszámnak.

A súlyszámösszeg vizsgálata az ágyszámok és az elszámolt esetek számától eltérő megoszlást hozott. Ezek alapján az egyetemi maxillofacialis osztályokon jelentett esetek súlyszámösszege 4998,75, ami az országos adat 48\%-a. A fơvárosi és egyéb intézetek részaránya a súlyszámösszeg tekintetében hasonló az ágyszámokhoz (9\%), vagyis a megyei intézetek térnek el a finanszírozott esetek százalékos megoszlásától negatív irányban. A megyei intézetek esetén a súlyszámösszeg $41 \%$ volt.

$\mathrm{Az}$ 1. táblázat további elemzésével összevethetjük a case-mix indexeket is. A case-mix (eset-összetételi) index HBCs- (Homogén Betegcsoport) alapú elszámolásban

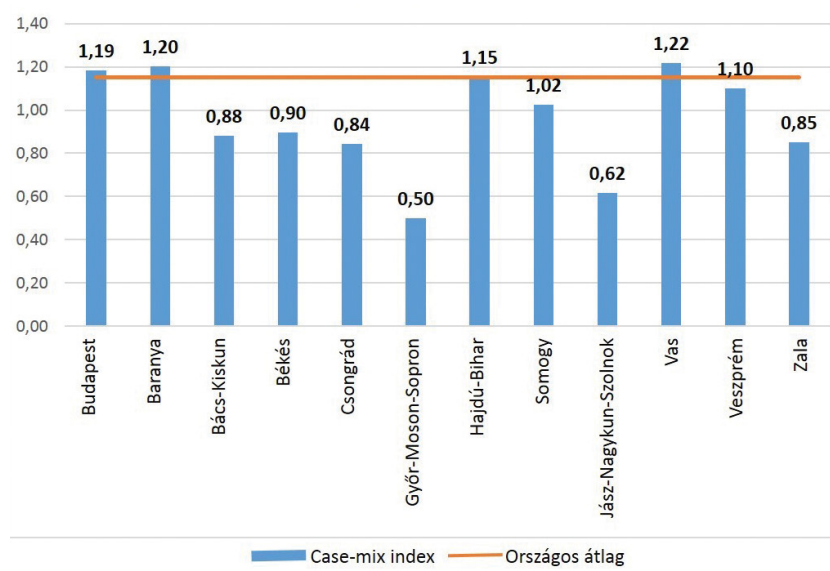

\begin{tabular}{l|l} 
1. ábra & $\begin{array}{l}\text { Az egyes megyék arc-, állcsont-szájsebészeti aktív fekvóbeteg- } \\
\text { ellátására jellemző case-mix index értékek az országos átlaghoz } \\
\text { viszonyítva (2015) }\end{array}$
\end{tabular}

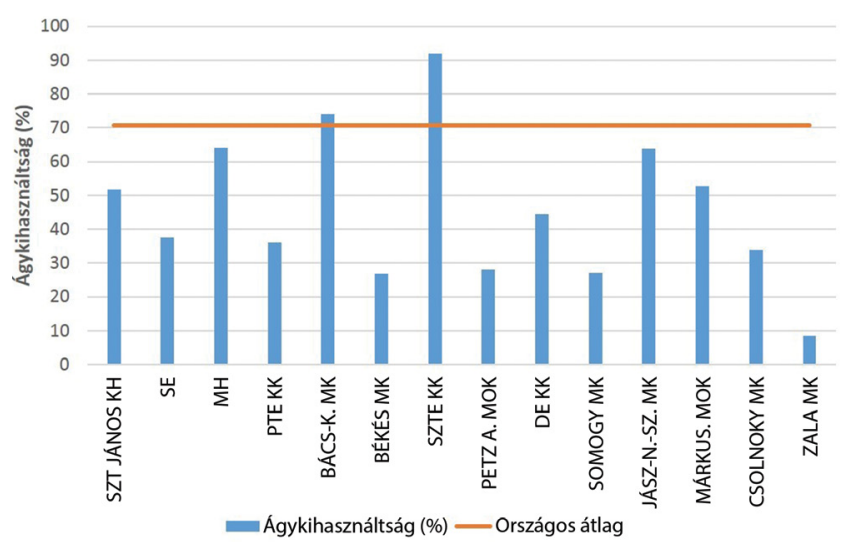

2. ábra $\mid \begin{aligned} & \text { Az egyes intézetek ágykihasználtsága és az országos átlag } \\ & \text { (2015) }\end{aligned}$ (2015)

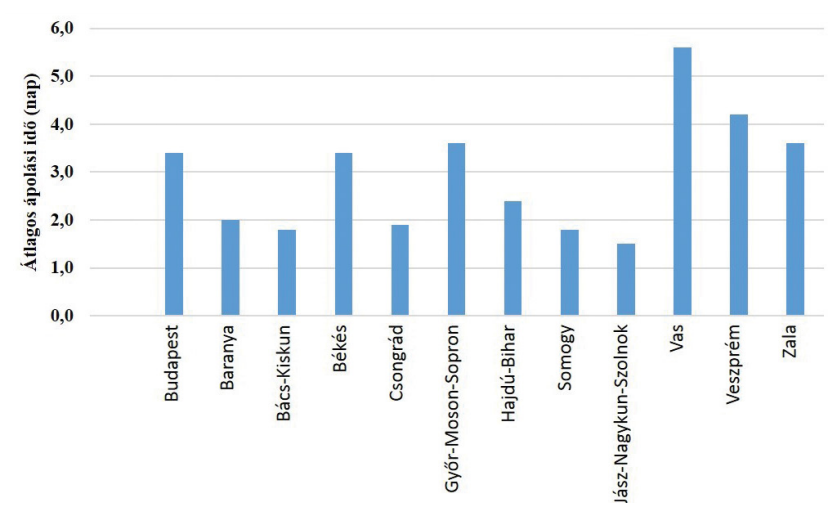

3. ábra $\quad$ A maxillofacialis beavatkozások átlagos ápolási ideje megyei bontásban és Budapesten (2015)

használt, az aktív fekvőbeteg-ellátás finanszírozási rendszere szerint elszámolható, adott időszak alatt ellátott finanszírozási esetek összetételét költségigényesség szempontjából jellemző mutató, amely az elszámolt súlyszám és az elszámolt finanszírozási esetszám hányadosa. Értéke átlagos szakmai igényességú ellátások esetén: 1. Az ennél magasabb szám azt jelzi, hogy az intézmény az átlagosnál magasabb szakmai színvonalú vagy 


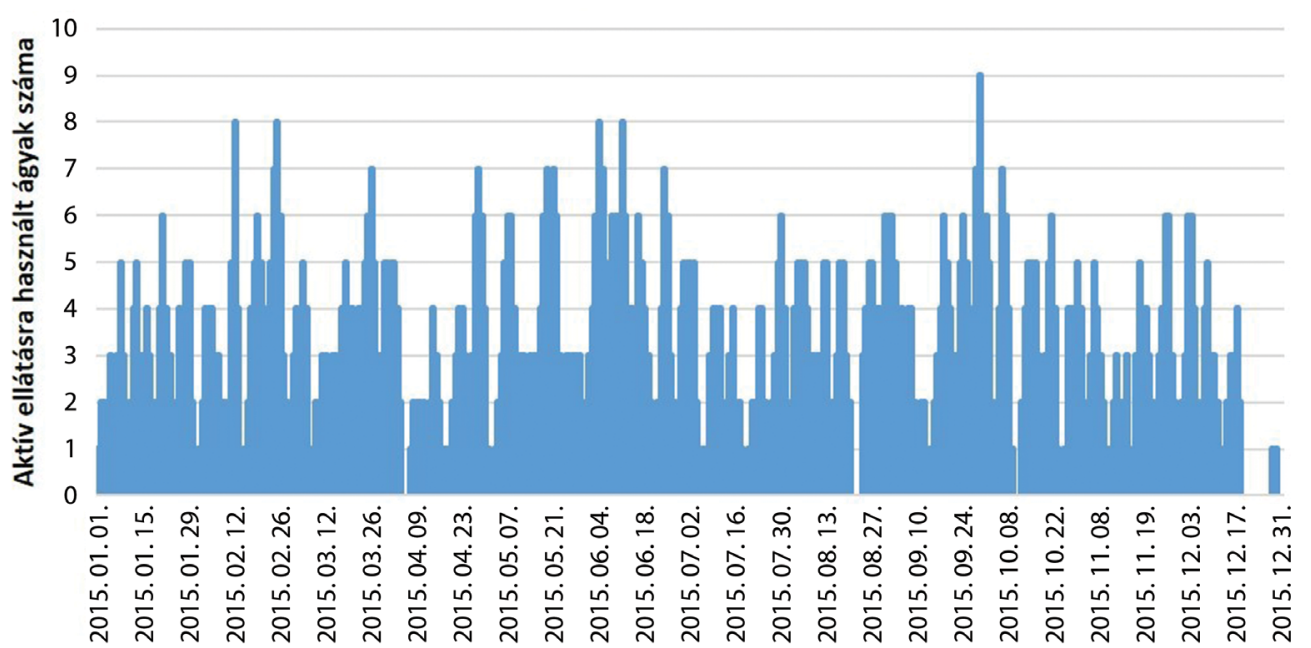

4. ábra

| Napi ágykihasználtság a PTE KK Fogászati és Szájsebészeti Klinika Arc-, állcsont-szájsebészeti fekvőbetegosztályán 2015-ben

nagyobb bonyolultságú eseteket kezel. Ennek megfelelően azt várjuk, hogy az egyetemi klinikák magasabb case-mix indexértékkel rendelkezzenek, amit a táblázatunk alá is támaszt. Az egyetemek értéke 1,09769, míg a megyei intézeteké 0,83180. A Magyar Honvédség Egészségügyi Központjának mutatói az egyetemeken látottakhoz közeli értéket mutatott (1,06659).

Az elszámolt ápolási napokat vizsgálva ismételten ágyszámarányos megoszlást kapunk. Az egyetemi klinikák összesen 11065 (41\%) napot számolhattak el, míg a megyei intézetek esetén ez a szám 12126 (45\%).

A 2. táblázatban az egyes intézményeket külön-külön is értékelhetjük. A négy egyetemi klinika közül a Semmelweis Egyetem rendelkezik a legmagasabb ágyszámmal (26), ezt követi a Debreceni Egyetem (18), majd a Szegedi Egyetem (11), és legkevesebb ágy a Pécsi Tudományegyetem klinikáján található (10).

A finanszírozási eseteket vizsgálva a négy egyetemi klinikán, a Debreceni Egyetem és a Pécsi Tudományegyetem Klinikai Központjának klinikáin a megoszlás közel ágyszámarányos. Jelentős viszont az eltérés a Semmelweis Egyetem és a Szegedi Tudományegyetem esetében.

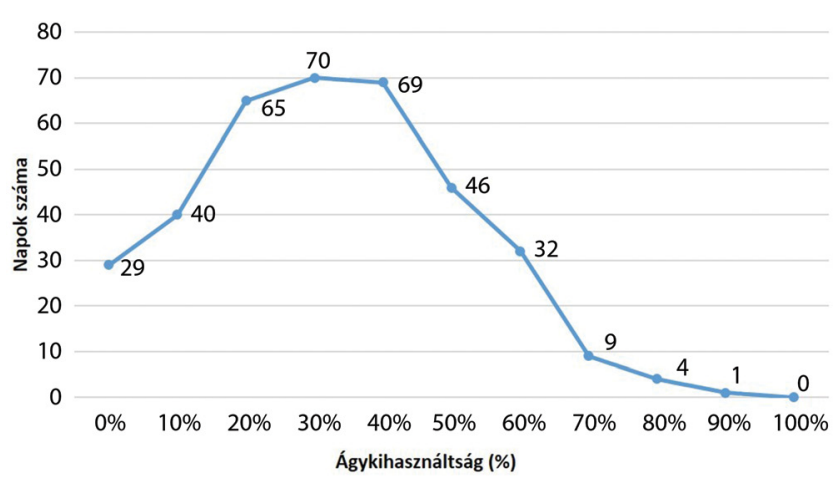

5. ábra $\mid$ Az ágykihasználtság eloszlása a PTE KK Fogászati és Szájsebészeti Klinika Arc-, állcsont-szájsebészeti fekvőbetegosztályán (2015)
Előbbiben található az egyetemi ágyszámok 40\%-a, viszont a klinikákon ellátott eseteknek csak 21\%-a (975) köthető ehhez az intézményhez. A Szegedi Egyetem klinikájával pedig fordított a helyzet. A viszonylag alacsony ágyszám ellenére a klinikák által ellátott esetek 43\%-át (1988) itt kezelték.

A megyei intézmények közül szembetűnő a Bács-Kiskun Megyei Oktatókórház teljesítménymutatója, hiszen a megyei intézmények teljes finanszírozási esetszámának $50 \%$-át és az országos teljes esetszámnak is a $24 \%$-át ebben az intézményben jelentették az egészségpénztár felé. Ennek megfelelően a súlyszámok összege is ebben az intézményben a legmagasabb, megelőzve mind a négy egyetemi klinikát és a további intézeteket is.

Ha a teljesítménymutatók közül az egy aktív ágyra jutó súlyszámot vizsgáljuk, az adatok rendkívül nagy szórást mutatnak. Két intézmény rendelkezik az átlaghoz képest $(60,74)$ lényegesen magasabb értékkel. A Bács-Kiskun Megyei Oktatókórház esetén ez az érték 149,95, míg a Szegedi Tudományegyetem klinikájánál ez 151,36. Az átlaghoz képest negatív irányú jelentős eltérést pedig a Petz Aladár Megyei Oktató Kórház $(15,11)$ és a Zala Megyei Kórház $(3,4)$ mutat.

A case-mix index összevetésében az egyetemi klinikák közül a szegedi 1 alatti értéket ért el $(0,845)$, míg a másik három mind 1 feletti mutatóval szerepel. A többi intézet adatait áttekintve látható, hogy a megyei intézetek közül is volt olyan, ami l fölötti indexértéket ért el (Csolnoky Ferenc Kórház: 1,1; Markusovszky Egyetemi Oktatókórház: 1,22; Somogy Megyei Kaposi Mór Oktató Kórház: 1,02), valamint egy nem megyei intézmény is (Magyar Honvédség Egészségügyi Központ: 1,06) hasonló eredményeket ért el. Legalacsonyabb indexértéket a Petz Aladár Megyei Oktató Kórház esetén találtunk. $\mathrm{Az}$ intézetek case-mix index értékeit, illetve azoknak az országos átlagtól való eltérését mutatja az 1 ábra.

Ezt követően részletesen megvizsgáltuk az arc-, állcsont-szájsebészeti osztályok ágykihasználtságát (2. ábra). Ehhez a teljesített betegnapok és az ágyak számának 
adott időszakra számított átlagát vettük alapul. Az adatok elemzése során azt tapasztaltuk, hogy az arc-, állcsont-szájsebészeti fekvőbetegosztályok ágykihasználtságának országos átlagértéke $(45,75)$ elmarad az országos átlagtól $(70,81)$. Az intézetek közül csak a szegedi klinika $(91,93)$ és a kecskeméti kórház $(70,81)$ ért el az országos átlagnál magasabb értéket. A további három egyetemi klinika mind elmarad a maxillofacialis osztályok átlagától. Legalacsonyabb ágykihasználtsági értéket a zalaegerszegi kórház kapcsán találtuk, amelynek kihasználtsága éves átlagban nem érte el a 10\%-ot $(8,49)$, amivel a többi hasonló osztálytól is messze elmaradt. Ugyan nem ennyire alacsony, de az országos átlag felét sem éri el ez a teljesítménymutató a Somogy Megyei Kaposi Mór Oktató Kórház $(27,2)$, a Petz Aladár Megyei Oktató Kórház (28) és a Békés Megyei Pándy Kálmán Kórház $(26,83)$ esetén a megyei intézetek közül.

Ezt követôen az átlagos kezelési idő került elemzésre (3. ábra). Ebben az elemzésben az egyetemi klinikák hasonló, 2 körüli értéket értek el. Legmagasabb volt a Markusovszky Egyetemi Oktatókórház értéke $(5,6)$, legalacsonyabbat pedig a Jász-Nagykun-Szolnok Megyei Hetényi Géza Kórházhoz kapcsolódóan találtuk $(1,5)$.

Végezetül a Pécsi Tudományegyetem, Klinikai Központ, Fogászati és Szájsebészeti Klinika Arc-, állcsontszájsebészeti fekvőbetegosztályának ágykihasználtsági mutatóit vizsgáltuk napi bontásban (4. ábra), illetve az ágykihasználtság megoszlását (5. ábra). A 4. ábrából leolvasható, hogy a vizsgált naptári évben az osztály tíz aktív ágyán egyetlen napon volt 90\%-os a kihasználtság és $80 \%$-ot is csak négy napon értek el. Ezzel szemben sokkal magasabb azoknak a napoknak a száma, amikor csak egy ágy volt kihasználva, és olyan időszakot is találunk, amikor az ágyakon egyáltalán nem folyt ellátás. Az 5. ábra szemléletesen mutatja, hogy 29 napon nem volt fekvőbeteg-ellátás, és az év jelentős részében (204 naptári napon) 20-40\%-os kihasználtsággal múködött az osztály.

\section{Megbeszélés}

A maxillofacialis sebészet nemcsak hazánkban, hanem az iparilag fejlett országokban fontossága ellenére is alulfinanszírozott szakmának számít. Ennek egyik oka a különböző betegbiztosítási és finanszírozási rendszerekben keresendő. Példaként említhetjük az Egyesült Államokat, ahol a fej-nyak terület traumatológiai ellátásának költségeit mindössze alig 40\%-ban finanszírozzák, ami arra vezethető vissza, hogy a pácienseknek csak kis százaléka rendelkezik megfelelő biztosítással [8]. Szakmai szempontból viszont ez a szakterület rendkívül összetett és számos társszakma alapos ismeretét igényli. A fogászattal való szoros kapcsolatát is jól mutatja, hogy számos országban a fej-, nyaksebészet múvelőinek az általános orvosi diploma mellett fogorvosival is rendelkezniük kell [9-13].
A maxillofacialis beavatkozások magas költségei miatt számos országban (például Franciaország, Egyesült Államok) tettek különböző intézkedéseket a szúkös források legoptimálisabb allokációjára [14, 15]. Hagyományosan a nagyobb fej-nyak terület sebészi beavatkozásai intézeti ellátáshoz és kórházi ápoláshoz kapcsolódnak. Ennek elsődleges okai között szerepel az altatás utáni megfigyelés szükségessége, a légutak potenciális instabilitása, vérzés veszélye, a szájon át történő táplálás nehezítettsége és a fájdalomkontroll. Az ebből adódó magas költségek csökkentésére számos eredményes próbálkozás született például az egynapos sebészet bevezetésével, amit az általános érzéstelenítés és a mütéti technikák rohamos fejlődése tett lehetővé [16-20].

Magyarországon az egészségügyben az utóbbi évtizedek egyik legnagyobb kérdése a szúkös források leghatékonyabb elosztása [21-25]. Számos döntés és határozat mentén több alkalommal is mélyreható kórházi ágyszámátrendezés történt, ami érintette az aktív ágyak számát és az egyes szakmák közötti megoszlásukat is. Sajnálatos módon az arc-, állcsont-szájsebészeti fekvőbetegosztályok száma csökkent az osztályokhoz tartozó ágyszámkapacitásokkal együtt. Mindezek miatt a 42335 aktív ágyból csak 162 volt kapcsolható a 17-es szakmakódhoz a vizsgált időszakban. Ezzel a harmadik legkevesebb ágygyal rendelkező fekvőbeteg-ellátási forma és csak a plasztikai és égéssebészetet (156 ágy), valamint a gyermek- és ifjúságpszichiátriát (138) előzi meg. A szakmai kollégium szerint ez a szám rendkívül alacsony, annak ellenére, hogy az utóbbi években az arc-, állcsont-szájsebészeti osztályok jelentősége egyre fokozódott, amit számos adat is alátámaszt. 2011 és 2015 között például Baranya megyében az állcsonttörést okozó traumás sérülések száma 67-ról 124-re emelkedett (nem publikált adat). Ugyan némi javulás a fej-nyak terület rosszindulatú daganatainak mortalitásában és morbiditásában is mutatkozik, de még mindig vezetők vagyunk ebben a mutatóban Európában. A növekvő esetszám ellenére számos nehézség miatt a maxillofacialis osztályok nehezen tudják kapacitásaikat növelni. Szinte valamennyi ellátóhely teljes mértékben kihasználja a teljesítményvolumen-korlát (TVK) által nyújtott lehetőségeket, és ezért az akut ellátások számának emelkedésével elsősorban az elektív beavatkozások számának emelkedése és akár várólisták kialakulása is valószínúsíthető.

Az egészségbiztosító hazánkban törvényi kötelezettsége mentén - 2006. évi CXXXII. törvény 4. \$ (1) bekezdése - rendszeresen vizsgálja azokat az indikátorokat és teljesítménymutatókat, amelyek segítségével elemzi többek között a szakellátást nyújtó egészségügyi szolgáltatók lekötött kapacitásának kihasználtságát és a kapacitásváltozás szükségességét. Jelenleg az ágyszámok eloszlása egyenetlen, a lakosság közel 50\%-a olyan helyen él, ahol nincs arc-, állcsont-szájsebészeti ellátás. A progreszszív betegellátás mentén pedig az egyetemi klinikák ágyszáma is döntően magasabb, mint a regionális ellátást nyújtó megyei intézetekben. Kivétel ez alól a kecskeméti 
és győri oktatókórház, ahol magasabb ágyszámmal találkozunk, mint a pécsi és a szegedi klinika esetén. Kecskeméten a finanszírozási esetek és a súlyszámösszeg magas száma indokolja is ezt az ágyszámot, a Petz Aladár Megyei Oktató Kórház esetén viszont nem támasztja alá.

A biztosító a teljesítménymutatók és indikátorok közül az ágykihasználtsági adatokat is figyelembe veszi a szükséges kapacitások tervezésekor. Az eltérő szakmák gyakran eltérő ágykihasználtsággal rendelkeznek, és ezért nem is lehet egy mútétes szakmát egy belgyógyászati osztállyal összevetni ezen mutató kizárólagos figyelembevételével. A sebészeti szakma ágykihasználtsága a vizsgált időszakban alig haladta meg a $65 \%$-ot $(67,51 \%)$, viszont a szakmához kapcsolódó kórházi ágyak száma 4599 volt, szemben az arc-, állcsont-szájsebészeti osztályok 162 ágyával. A maxillofacialis sebészethez hasonló ágyszámmal dolgozó manuális szakmaként a plasztikai és égéssebészetet hozhatjuk példaként, ahol az országos ágykihasználtság nagyon hasonló arányt mutat (54,79\%) az arc-, állcsont-szájsebészettel. Ezek az adatok is mutatják, hogy a manuális szakmákban az alacsony ágyszám alacsony kihasználtságot eredményez. Az arc-, állcsontszájsebészeti osztályok esetén ezen túlmenően további speciális szempontokat is figyelembe kell venni ennek az indikátornak a vizsgálata során. Az alacsony ágyszámú osztályok esetén a férfi-nő betegek felvételének tervezhetősége, valamint a sürgősségi esetek számára fenntartott ágykapacitás, illetve a fej-nyaki régióban kiemelt jelentőségű fertőző, gyulladásos betegek szakmailag indokolt elkülönítése mind hatással van az ágykihasználtságra. Ezenkívül mindössze négy olyan intézmény van hazánkban, ahol az állandó aneszteziológiai háttér biztosított, a többi ellátóhelyen általában heti két napra korlátozódik az általános érzéstelenítésben végzett ellátások lehetősége. Az országban több helyen fogászati centrumokat adtak át fogyatékkal élők ellátásának javítására, ami sok esetben szintén a maxillofacialis osztályok ágyszám-kapacitásainak terhére valósult meg. Azt, hogy a betegellátásban mégsem alakult ki eddig nehézség, az többek között a korszerü anyagok és módszerek alkalmazásának és a megfelelő szakmai háttérnek köszönhető, amely képes volt megteremteni az egynapos sebészet hátterét. A későbbiekben is valószínüsíthető, hogy egyre nagyobb szerep hárul majd erre az ellátási formára.

Ahogy arra korábbi tanulmányok rámutattak, a teljesített betegnapok és az ágyak számának adott évre számított átlaga sok esetben nem tükrözi a valós viszonyokat [26]. Gresz és mtsai a napi ágykihasználtság megoszlását javasolja, ami grafikusan jól ábrázolható és sokkal jobban mutatja a tényleges ágykihasználtságot. A Pécsi Tudományegyetem Fogászati és Szájsebészeti Klinikájának adataiból elkészítettük a napi ágykihasználtság (4. ábra) és a napi ágykihasználtság megoszlásának grafikonját (5. ábra) a vizsgált időszakra. Ennek a grafikonnak az elemzésével választ kereshetünk olyan kérdésekre, hogy van-e az évnek olyan időszaka, amikor az ágyak leginkább ki- használtak, illetve van-e olyan, amikor szinte üresen állnak.

Mindezeken túl talán a legnagyobb gondot a szakorvoshiány jelenti. A vizsgált időszakban sem volt már minden intézményben maxillofacialis szakvizsgával rendelkező szakember. Sajnálatos módon ez a tény is közrejátszott abban, hogy a vizsgált időszak óta eltelt időben újabb két osztály múködése szűnt meg (Veszprém, Zalaegerszeg), emelve ezzel a megmaradt osztályok terheltségét. Ezzel együtt a területi egyenetlenség is tovább romlott.

Az adatokból látható, hogy az ágyszámkapacitások és a volumenkorlát emelése nélkül az arc-, állcsont-szájsebészeti osztályok teljesítménymutatói érdemben nem javíthatók. Emellett rendkívül nagy jelentőségú az utánpótlás-nevelés hatékonyságának fokozása is. Ennek első lépcsőjeként a maxillofacialis sebészi szakmát hiányszakmává nyilvánították és az ezzel együtt járó, többek között magasabb pénzbeli juttatások is hozzájárulhatnak ahhoz, hogy minél több pályakezdő orvos válassza ezt a szakmát hivatásául.

\section{Következtetés}

Megállapítható, hogy a vizsgált időszakban a különböző indikátorok jelentős eltérést mutattak az egyes intézmények között. Elemzésekhez, rövid és hosszú távú stratégia kialakításához ezért szükséges több indikátor egyidejű elemzése. Új indikátor, mint például az ágykihasználtság-eloszlás vizsgálata még hatékonyabbá teheti az elemzőmunkát.

Anyagi támogatás: A cikk megírása anyagi támogatásban nem részesült.

Szerzői munkamegosztás: M. Gy.:A hipotézis kidolgozása, a kézirat megszövegezése. N. Á.: A hipotézis kidolgozása. S. A., B. I.: A hipotézis kidolgozása, adatok elemzése. Z. A.: Az adatok elemzése. R. M.: A hipotézis kidolgozása, a kézirat végső korrekciója. A cikk végleges változatát valamennyi szerző elolvasta és jóváhagyta.

Érdekeltségek: A szerzőknek nincsenek érdekeltségeik.

\section{Irodalom}

[1] Kóbor, A.: Commemorating the foundation of the dental clinics. I. The foundation of the Stomatology Clinic (Budapest, Hungary). [Az egyetemi fogászati klinikák alapításának évfordulóira. I. A Stomatológiai Klinika megalapítása.] Fogorv. Sz., 2009, 102(6), 235-241. [Hungarian]

[2] Statute of the Minister of Health of healthcare providers and registration of business licenses, as well as the list of health professional. [2/2004. (XI. 17.) EüM rendelet az egészségügyi szolgáltatók és múködési engedélyük nyilvántartásáról, valamint az egészségügyi szakmai jegyzékről.] Available from: https://net. jogtar.hu/jr/gen/hjegy_doc.cgi?docid=a0400002.eum [Hungarian] 
[3] Suri, Cs.: Changing in the organization of oral surgery and dental care according to the NATO's principles. PhD thesis. [A fogászati és szájsebészeti ellátás szervezési, valamint klinikai elveinek változása a NATO követelményeinek megvalósítása érdekében. PhD-értekezés.] Zrínyi Miklós Nemzetvédelmi Egyetem, Kossuth Lajos Hadtudományi Kar, Hadtudományi Doktori Iskola, Budapest, 2010. [Hungarian]

[4] Boncz, I., Nagy, J., Sebestyén, A., et al.: Financing of health care services in Hungary. Eur. J. Health Econ., 2004, 5(3), 252-258.

[5] Endrei, D., Molics, B., Ágoston, I.: Multicriteria decision analysis in the reimbursement of new medical technologies: real word experiences from Hungary. Value Health, 2014, 17(4), 487489.

[6] Boncz, I., Evetovits, T., Dózsa, Cs., et al.: The Hungarian Care Managing Organization Pilot Program. Value Health Regional, $2015,7 C, 27-33$

[7] Greenberg, D., Ibrabim, M. I., Boncz, I.: What are the challenges in conducting cost-of-illness studies? Value Health Regional, 2014, 4, 115-116.

[8] Khansa, I., Khansa, L., Pearson, G. D.: Surgeon reimbursements in maxillofacial trauma surgery: effect of the affordable care act in Ohio. Plast. Reconstr. Surg., 2016, 137(2), 613-618.

[9] Gigliotti, J., Makhoul, N.: Demographics, training satisfaction, and career plans of Canadian oral and maxillofacial surgery residents. Int. J. Oral Maxillofac. Surg., 2015, 44(12), 1574-1580.

[10] Wisaijobn, T., Pimkbaokham, A., Lapying, P., et al.: New casemix classification as an alternative method for budget allocation in Thai oral healthcare service: a pilot study. Int. J. Dent., 2010, 2010, ID 231398. doi:10.1155/2010/231398

[11] Zweifel, D. F., Simon, C., Hoarau, R., et al.: Are virtual planning and guided surgery for head and neck reconstruction economically viable? J. Oral Maxillofac. Surg., 2015, 73(1), 170-175.

[12] Tighe, D., Sassoon, I., Kwok, A., et al.: Is benchmarking possible in audit of early outcomes after operations for head and neck cancer? Br. J. Oral Maxillofac. Surg., 2014, 52(10), 913-921.

[13] Naran, S., Hudovsky, A., Antscherl, J., et al.: Audit of accuracy of clinical coding in oral surgery. Br. J. Oral Maxillofac. Surg., 2014, 52(8), 735-739.

[14] Baujat, B., Altabaa, K., Meyers, M., et al:: Medicoeconomic study of microsurgical head and neck reconstructions. Eur. Ann. Otorhinolaryngol. Head Neck Dis., 2011, 128(3), 121-126.

[15] Dann, J. J.: Outpatient oral and maxillofacial surgery: transition to a surgicenter setting and outcome of the first 200 cases. J. Oral Maxillofac. Surg., 1998, 56(5), 572-577.
[16] Hu, M. L., Perrott, D. H., Rinaldi, R. C., et al.: Outcomes research: a mandate for oral and maxillofacial surgery (Part I). J. Oral Maxillofac. Surg., 2000, 58(1), 91-95.

[17] Erdmann, D., Price, K., Reed, S., et al.: A financial analysis of operative facial fracture management. Plast. Reconstr. Surg., 2008, 121(4), 1323-1327.

[18] Moses, H., Powers, D., Keeler, J., et al.: Opportunity cost of surgical management of craniomaxillofacial trauma. Craniomaxillofac. Trauma Reconstr., 2016, 9(1), 76-81.

[19] Yuvaraj, V.: Maxillofacial infections of odontogenic origin: epidemiological, microbiological and therapeutic factors in an Indian population. Indian J. Otolaryngol. Head Neck Surg., 2016, 68(4), 396-399.

[20] Stamate, M., Chiriac, N. D.: Retrospective analysis of use and distribution of resources in otolaryngology wards in Romanian hospitals between 2003 and 2008 to improve provision and financial performance of healthcare services. Croat. Med. J., 2010, 51(3), 259-266.

[21] Boncz, I., Sebestyén, A.: Financial deficits in the health services of the UK and Hungary. Lancet, 2006, 368(9539), 917-918.

[22] Boncz, I., Vajda, R., Agoston, I., et al.: Changes in the health status of the population of Central and Eastern European countries between 1990 and 2010. Eur. J. Health Econ., 2014, 15(Suppl 1), S137-S141.

[23] Boncz, I, Sebestyén, A.: Health-economics and health insurance aspects of Mendelian randomization. Am. J. Clin. Nutr., 2016, $104(6), 1720$.

[24] Cs. Horváth, Z., Sebestyén, A., Österle, A., et al.: Economic burden of long-term care of rheumatoid arthritis patients in Hungary. Eur. J. Health Econ., 2014, 15(Suppl. 1), S131-S35.

[25] Endrei, D., Zemplényi, A., Molics, B., et al.: The effect of performance-volume limit on the DRG based acute care hospital financing in Hungary. Health Policy, 2014, 115(2-3), 152-156.

[26] Gresz, M.: Novel indicator for the assessment of hospital bed occupancy. [Az ágykihasználtság jellemzésének új lehetősége.] Orv. Hetil., 2011, 152(20), 797-801. [Hungarian]

(Marada Gyula dr., Pécs, Mária u. 5-7., 7621 e-mail: marada.gyula@pte.hu)

\title{
A rendezvények és kongresszusok híranyagának leadása
}

\author{
a lap megjelenése előtt legalább 40 nappal lehetséges, a 6 hetes nyomdai átfutás miatt. \\ Kérjük megrendelőink szíves megértését.
}

A híranyagokat a következő címre kérjük:

Orvosi Hetilap titkársága: edit.budai@akademiai.hu

Akadémiai Kiadó Zrt. 